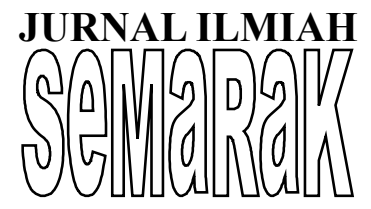

P-ISSN 2615-6849, E-ISSN 2622-3686

Jurnal Semarak,Vol. 2,No.2, Juni 2019, Hal (35- 50)

(a)Prodi Manajemen Fakultas Ekonomi Universitas Pamulang

\title{
PENGARUH GAYA KEPEMIMPINAN, MOTIVASI KERJA DAN LINGKUNGAN KERJA TERHADAP KEPUASAN KERJA PADA KANTOR BALAI BESAR BMKG WILAYAH 2 CIPUTAT
}

\author{
Nanda Rodiyana, Shelby Virby \\ Staf Pengajar Fakultas Ekonomi Universitas Pamulang \\ Email: nandaattalon@gmail.com
}

\begin{abstract}
ABSTRAK
Penelitian ini memiliki tujuan untuk mengetahui pengaruh secara parsial antara gaya kepemimpinan terhadap kepuasan kerja di Kantor Balai Besar BMKG wilayah 2 Ciputat, untuk mengetahui pengaruh secara parsial antara motivasi kerja terhadap kepuasan kerja di Kantor Balai Besar BMKG wilayah 2 Ciputat dan untuk mengetahui pengaruh secara simultan antara gaya kepemimpinan dan motivasi kerja terhadap kepuasan kerja di Kantor Balai Besar BMKG wilayah 2 Ciputat. Data yang digunakan dalam penelitian ini menggunakan data primer yang diperoleh dari jawaban dari responden yang menjadi pegawai di Kantor Balai Besar BMKG wilayah 2 Ciputat yang diberikan kuesioner. Pemilihan sampel dilakukan dengan menggunakan rumus slovin. Hasil penelitian ini menunjukkan bahwa terdapat pengaruh secara simultan pada variabel gaya kepemimpinan, motivasi kerja dan lingkungan kerja terhadap kepuasan kerja. Hasil penelitian ini juga menunjukkan variabel gaya kepemimpinan, motivasi kerja dan lingkungan kerja berpengaruh signifikan secara parsial terhadap kepuasan kerja. Pada koefisien determinasi terdapat pengaruh sebesar $81,1 \%$ yang mempengaruhi kepuasan kerja yang dijelaskan oleh variabel gaya kepemimpinan, motivasi kerja dan lingkungan kerja, sedangkan sisanya $18,9 \%$ dipengaruhi oleh variabel lain dan tidak termasuk kedalam analisis regresi ini.
\end{abstract}

Kata kunci: gaya kepemimpinan, motivasi kerja, lingkungan kerja, kepuasan kerja

\section{ABSTRACT}

This research aims to know the influence of partially between leadership style towards job satisfaction in the offices of Large Hall area 2 BMKG Ciputat, to know the influence of partially between motivation work towards job satisfaction in The Office of the Balai Besar BMKG region 2 Ciputat and to know the influence of simultaneously between leadership style and motivation work towards job satisfaction in the Office of the Balai Besar BMKG region 2 Ciputat. The data used in this research using primary data obtained from answers from respondents who became a clerk in the Office of the Balai Besar BMKG region 2 Ciputat provided questionnaire. The selection of the samples was done using the formula slovin. The results of this research show that there are simultaneous influence on the variable style of leadership, work motivation and job satisfaction toward the work environment. The results of this research also indicates the variable style of leadership, work motivation and significantly influential work environment partially towards job satisfaction. On the coefficient of determination there are $81.1 \%$ of influence that affect job satisfaction variable explained by the leadership styles, motivation of work and work environment, while the remaining $18.9 \%$ is affected by other variables and does not include into this regression analysis.

Keywords: leadership styles, motivation to work, the work environment, job satisfaction 
JURNAL ILMIAH

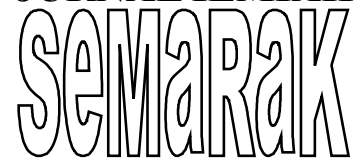

\section{PENDAHULUAN}

\section{A. Latar Belakang}

Karyawan merupakan salah satu aset syarikat penting dan perlu diuruskan dan dibangunkan untuk menyokong kelangsungan hidup syarikat. Syarikat ini juga menghadapi cabaran besar untuk memenangi pertandingan, begitu juga taktik dan strategi yang tepat. Dalam memilih taktik dan strategi, syarikat bukan sahaja memerlukan analisis perubahan dalam persekitaran luaran seperti demografi, sosio-kebudayaan, politik, teknologi dan persaingan, tetapi juga perlu menganalisis faktor dalaman syarikat. Faktor dalaman yang dipersoalkan adalah kekuatan dan kelemahan syarikat dalam usaha untuk menyokong dan mencapai sasaran yang ditetapkan. Faktor internal akan menyebabkan semakin buruknya kondisi perusahaan karena adanya perbedaan sikap, perasaan, pikiran dan karakteristik setiap pegawai (Ardana, 2012:17).

Manajemen sumber daya manusia merupakan proses mengenal pasti, menggalakkan, mengukur, menilai, meningkatkan dan memberi ganjaran prestasi pekerja. Definisi lain dinyatakan oleh Dessler (2005) dalam Riani (2013: 63) yang menyatakan bahawa pengurusan sumber manusia adalah proses yang menyatukan penetapan tujuan, penilaian prestasi dan pembangunan satu sistem yang bertujuan untuk memastikan prestasi pekerja menyokong dan sesuai dengan tujuan perusahaan.

Salah satu organisasi yang membutuhkan manajemen sumber daya manusia adalah instansi Balai besar badan meteorologi, klimatologi dan geofisika. (BMKG) Hal ini dikarenakan instansi BMKG merupakan unit pelaksanaan teknis yang salah satu tugas pokoknya memberikan pelayanan kepada masyarakat.

Pekerja yang mendapat kepuasan kerja akan melakukan pekerjaan mereka dengan lebih baik, pekerja yang tidak mendapat kepuasan kerja tidak akan mencapai kematangan psikologi yang akan menyebabkan kekecewaan. Pekerja seperti ini selalunya meratap, semangat yang rendah, cepat bosan dan letih, emosi yang tidak stabil, sering tidak hadir dan sibuk melakukan apa-apa kaitan dengan kerja yang mesti dilakukan (Hasibuan, 2012: 32). Kepuasan tinggi akan membawa kepada tahap rendah dan ketidakhadiran yang rendah kerana individu yang berpuas hati digalakkan untuk bekerja dengan lebih baik kerana pentingnya berpuas hati. Apabila seorang pekerja merasa puas dalam kerja maka seorang pekerja akan berusaha untuk menyelesaikan tugasnya, yang pada akhirnya akan menghasilkan kualiti perkhidmatan yang tinggi dan pencapaian tujuan syarikat. 


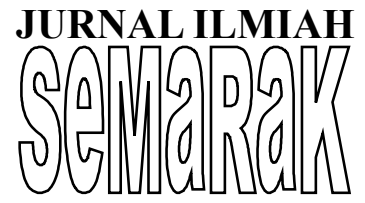

Gaya kepimpinan adalah salah satu faktor yang boleh mempengaruhi prestasi pekerja. Pendapat penulis ini sejalan dengan pendapat Ardana (2012:181) yang menyatakan bahwa kepemimpinan suatu organisasi akan mempengaruhi bawahannya, maka dengan kepemimpinan yang baik akan mempengaruhi kinerja yang baik pula.

Setiaap peemimpin paada daasarnya mempunyai tingkah laku yang berbeza dalaam memmimpin penngikutnya, tingkah laku pemmimpin dipanggil gaya kepimpinan. Kepimpinan memiliki hubungan yang sangat dekat dengan motivasi, kerana kejayaan seorang pemimpin dalam memindahkan orang lain dalam mencapai matlamat yang dimaksudkan sangat tergantung pada otoritas, dan juga pemimpin dalam menciptakan motivasi di dalam setiap subordinat, kolega dan pemimpin bos itu sendiri.

Kurangnya peranan kepimpinan dalam mewujudkan komunikasi harmoni dan menyediakan panduan pekerja akan membawa kepada tahap prestasi pekerja yang rendah. Begitu juga dengan kurangnya motivasi pekerja seperti tidak disiplin dalam kerja, kemalasan dalam kerja akan menyebabkan prestasi pekerja yang rendah. Setiap pemimpin pada dasarnya mempunyai tingkah laku yang berbeza dalam memimpin pengikutnya, tingkah laku pemimpin dipanggil gaya kepimpinan. Kepimpinan mempunyai hubungan yang sangat dekat dengan motivasi, kerana kejayaan seorang pemimpin dalam memindahkan orang lain dalam mencapai matlamat yang dimaksudkan sangat tergantung pada otoritas, dan juga pemimpin dalam menciptakan motivasi dalam setiap bawahan, kolega dan pemimpin bos itu sendiri.

Faktor motivator berkaitan dengan kerja yang menawarkan pencapaian, pengiktirafan, kerja yang mencabar, tanggungjawab dan prospek untuk kemajuan. Walaupun faktor kebersihan berkaitan dengan dasar syarikat, pengawasan, gaji, hubungan kerja dan keadaan kerja. Kesimpulannya, faktor kebersihan hanya dapat menghapuskan ketidakpuasan, tidak dapat meningkatkan kepuasan kerja, sementara faktor motivator dapat meningkatkan kepuasan kerja jika faktor ini ada.

Faktor lain yang mampu memberikan kepuasan bagi karyawan adalah lingkungan kerja, menurut Hemsath dan Yerkes (2006:2) lingkungan kerja yang menyenangkan berpengaruh positif pada produktivitas, kualitas, pelayanan konsumen dan kepuasan kerja. Lingkungan kerja yang kondusif memungkinkan karyawan lebih bersemangat dalam bekerja. Lingkungan kerja yang baik, bersih akan memotivasi karyawan dalam melakukan pekerjaan dengan baik. Dengan memperhatikan lingkungan kerja yang baik menciptakan 


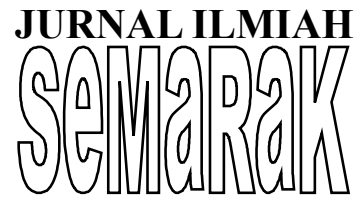

kondisi kerja yang mampu memberikan motivasi untuk bekerja (Isminar, 2015:124).

\section{B. Rumusan Penelitian}

Kepuasan kerja memiliki banyak faktor yang mempengaruhinya untuk mengetahuinya diperlukan analisa yang berdasarkan teori, maka rumusan penelitian permasalahan yang akan diteliti antara lain:

1. Apakah terdapat pengaruh secara parsial antara gaya kepemimpinan terhadap kepuasan kerja di Kantor Balai Besar BMKG wilayah 2 Ciputat?

2. Apakah terdapat pengaruh secara parsial antara motivasi kerja terhadap kepuasan kerja di Kantor Balai Besar BMKG wilayah 2 Ciputat?

3. Apakah terdapat pengaruh secara simultan antara gaya kepemimpinan dan motivasi kerja terhadap kepuasan kerja di Kantor Balai Besar BMKG wilayah 2 Ciputat?

\section{Tujuan Penelitian}

Berdasarkan latar belakang masalah dan perumusan masalah, maka tujuan dalam penelitian ini adalah sebagai berikut:

1. Unntuk mengetahui peengaruh seecara satu persatu antara gaya kepemimpinan teerhadap kepuuasan keerja di Kantor Balai Besar BMKG wilayah 2 Ciputat.

2. Unntuk meengetahui peengaruh secara parsial antara motivasi kerja terhadap kepuasan kerja di Kantor Balai Besar BMKG wilayah 2 Ciputat.
3. Untuk mengetahui pengaruh serentak antara gaya kepimpinan dan motivasi kerja terhadap kepuasan kerja di Kantor Balai Besar BMKG wilayah 2 Ciputat.

\section{TINJAUAN PUSTAKA}

\section{A. Manajemen Sumber Daya Manusia}

\section{Pengertian Manajemen}

"Manajemen berasal dari kata untuk mengelola, yang berarti mengelola, mengelola, mengelola, melaksanakan, dan mengendalikan. Manajemen adalah ilmu dan seni yang mengatur proses pemanfaatan sumber daya manusia dan sumber lain secara efektif dan efisien untuk mencapai tujuan tertentu" (Ardana, 2012:4).

Menurut Kasmir, "manajemen mengelola atau mengelola suatu kegiatan. Dalam arti sempit dikatakan bahwa manajemen mengelola perusahaan untuk mencapai tujuan melalui orang lain. Yang diatur dan dikelola adalah aset atau aset perusahaan, baik properti manusia, peralatan mesin, proses dan prosedur kerja. Aset ini perlu dikelola dengan baik, terus menerus dan berkesinambungan, jika Anda ingin menghasilkan hasil yang optimal seperti yang diharapkan" (Kasmir, 2016:10).

Menurut Lee dalam Swastha dan Sukotjo (2010:82) manajemen adalah ilmu dan seni merencanakan, mengorganisasi, mengarahkan, mengkoordinasikan serta mengawasi 


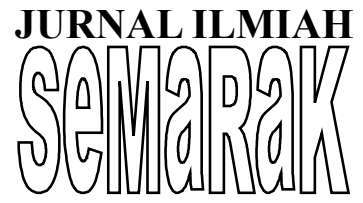

tenaga manusia dengan bantuan alatalat unntuk meencapai tuujuan yaang tellah dittetapkan. Darri defiinisi maanajemen tersebut dapat diambil suatu kesimpulan bahwa manajemen mempunyai lima fungsi, yaitu (proses perencanaan, proses pengorganisasian, pengarahan, pengkoordinasian dan pengawasan.

Kelima macam fungsi manajemen ini sangat penting di dalam menjalankan semua kegiatan. Semua ini dimaksudkan agar kegiatan apapun yang dilakukan dapat berjalan baik, sehiingga tuujuan yaang teelah diteetapkan dappat teercapai. Setiiap kegiiatan yaang dilakukan oleh seseorang atau sebuah lembaga tentu memiliki tujuan dan untuk mecapai tujuan perlu adanya perencanaan yang menggambarkan 1) Apa, 2) Bagaimana, 3) Mengapa dan 4) Kapan akan dilakukan (Swastha dan Sukotjo, 2010:82).

\section{Pengertian Sumber Daya Manusia}

Mengelola sumber daya manusia harus dilakukan secara benar sesuai dengan kaidah-kaidah kmanusiaan atau kodratnya. Jika di zaman dahulu manusia atau karyawan dianggap sebagai mesin yang dapat dilakukan dengan semena-mena demi mencapai tujuan perusahaan. Manusia dianggap sebagai budak yang dapat diperintah semaunya. Namun saat ini sesuai dengan perkembangannya, manusia semakin diperhatikan bahkan sekarang sudah berubah menjadi asset yang paling penting untuk diperhatikan (Kasmir, 2016:5).

Salah satu sumber organisasi yang mempunyai peranan penting dalam mencapai objektifnya adalah sumber manusia. Oleh karena pentingnya peran manusia dalam kompetisi baik jangka pendek maupun jangka panjang dalam agenda bisnis, suatu organisasi harus memiliki nilai lebih dibandingkan dengan organisasi lainnya. Organisasi yang berhasil dalam mempengaruhi pasar jika dapat menarik perhatian atas kelebihan yang dimiliki dalam berbagai hal dibandingkan dengan organisasi lain (Bangun, 2012:4).

Sutrisno (2016:3) mengatakan bahwa summber daaya maanusia meruupakan saatu-satunya sumber daya yang memiliki akal perasaan, keinginan, keterampilan, pengetahuan, dorongan, daya dan karya (rasio, rasa dan karsa). Semua potensi sumber daya manusia tersebut berpengaruh terhadap upaya organisasi dalam mencapai suatu tujuan.

\section{Pengertian Manajemen Sumber} Daya Manusia

$$
\text { Manajemen Sumber Daya }
$$

Manusia adalah proses pengelolaan manusia, melalui perencanaan, rekrutmen, seleksi, pelatihan, 


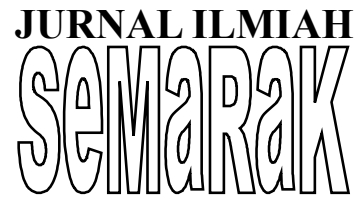

pengembangan,

kompensasi, karier, keselamatan dan kesehatan serta menjaga hubungan industrial sampai pemutusan hubungan kerja guna mencapai tujuan perusahaan dan peningkatan kesejahteraan stakeholder. Pengertian manajemen sumber daya manusia dari beberapa ahli MSDM: Noe menyebutkan Human Resources Management refers to Policies, practices and systems that influenza employees' behavior, attitudes, and performance (manajemen sumber daya manusia merupakan bagaiman mempengaruhi perilaku, sikap dan kinerja melalui kebijakan dan sistem yang dimiliki oleh perusahaan. Menurut Dessler Human Resources Management is the process of acquiring, training, appraising and compensating employees, and attending their labor relations, health and safety, and fairness concern (manajemen sumber daya manusia merupakan proses mengendalikan latihan penilaian pekerja, pampasan, kesihatan dan keselamatan pekerjaan dengan adil kepada fungsi MSDM.

Pengertian manajemeen summber daya manuusia addalah suatu kegiatan yang meliputi proses perencanaan, proses pengorganisasian, penyusunan personalia, penggerakan dan pengawasan terhadap fungsi-fungsi operasionalnya untuk mencapai tujuan perusahaan (Bangun, 2012:5).

Berdasarkan pengertian di atas maka dapat disimpulkan pengertian Mannajemen Summber Daaya Mannusia addalah segalah kegiatan dengan menggerakan summber dayya manuusia yang ada untuk mencapai tujuan perusahaan.

\section{B. Gaya Kepemimpinan}

Pemmimpin merrupakan seseeorang yanng memiiliki kemmampuan memmimpin arrtinya memmiliki kemaampuan unntuk mempengaruhi prilaku orang lain (Thoha, 1983) dalam (Ardana, dkk, 2012:179). Sedangkan kepemimpinan merupakan seluruh aktivitas dalam rangka mempengaruhi orang-orang agar mau bekerja sama mencapai suatu tujuan yang memang diinginkan bersama (Martoyo, 1990) dalam (Ardana, dkk, 2012:179).

Kepemimpinan (Leadership) adalah proses pengaruh sosial, yaitu suatu kehidupan yang mempengaruhi kehidupan lain, kekuatan yang mempengaruhi perilaku orang lain ke arah pencapaian tujuan tertentu (Soekarso dan Putong, 2015:9). Sedangkan pemimpin (Headship) adalah orang-orang yang memimpin atau para pemimpin (Supranto, 2007:24).

Berdasarkan pengertian para ahli di attas makaa dappat disimpullkan yaang dimaksud dengan kepemimpinan adalah suatu kemampuan yang dapat 


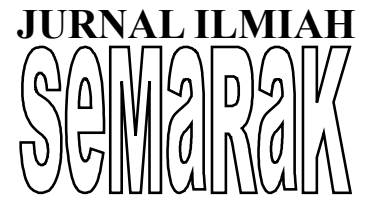

mempengaruhi dan menggerakkan orang lain dalam rangka mencapai suatu tujuan yang diinginkan bersama. Sedangkan yang dimaksud dengan pemimpin adalah seseorang yang mampu menggerakkan orang lain agar mau bekerja sehingga mencapai suatu tujuan bersama.

\section{Motivasi Kerja}

Ceramah motivasi tentang bagaimana untuk menggalakkan semangat seseorang, ingin bekerja dengan memberikan kemampuan dan kepakaran mereka untuk mencapai matlamat organisasi. Menurut motivasi Berelson dan Steiner adalah usaha yang sadar untuk mempengaruhi tingkah laku seseorang untuk dapat mencapai matlamat organisasi (Sunyoto, 2012: 11).

Menurut Wayne F. Cascio di Sunyyoto ( 2012:11) meenyatakan motivasi adalah daya yang dihasilkan dari keinginan seseorang untuk memenuhi kebutuhan mereka. Seperti halnya motivasi yang dinyatakan oleh Ardana, et al (2012: 193) yang menyatakan bahawa motivasi adalah kekuatan yang mendorong seseorang untuk melakukan tindakan atau tidak secara intinya ada secara dalaman dan eksternal yang boleh positif atau negatif untuk mengarahkannya bergantung pada ketangguhan pengurus .

Motivvasi kerja addalah sesuatu yang menimbulkan semangat atau semangat atau dorongan untuk bekerja semangat. Motif adalah penggerak atau penggerak yang menggalakkan manusia bertindak atau berkuatkuasa dalam manusia yang menyebabkan manusia bertindak (Ardana, et al, 2012: 193).

Menurut Wayne F. Cascio di Sunyoto (2012: 11) motivasi adalah daya yang dihasilkan dari keinginan seseorang untuk memenuhi kebutuhannya sebagai contoh; lapar, dahaga dan dahaga. Motivasi adalah daya yang menggalakkan seseorang mengambil tindakan atau tidak secara intinya ada secara dalaman dan luaran yang boleh positif atau negatif .

Motivasi adalah salah satu aspek penting dalam menentukan tingkah laku seseorang, termasuk tingkah laku kerja. Motivasi dapat ditafsirkan sebagai faktor faktor yang mengarahkan dan menggalakkan tingkah laku atau keinginan seseorang untuk melakukan suatu kegiatan yang dinyatakan dalam bentuk usaha keras atau lemah (Hariandja, 2007: 321).

Motivasi kerja menduduki kedudukan yang sangat penting dalam psikologi kerja, kerana motivasi bertanggungjawab menjawab soalan, mengapa kita bekerja? dan juga menangani cabaran dan kaedah untuk menghasilkan etika kerja pekerja untuk merealisasikan produktiviti yang ideal. Motivasi adalah sesuatu yang menggalakkan orang lain untuk mengambil tindakan pekerja juga mempunyai motivasi sehingga mereka ingin bekerja (Istijanto, 2010: 237).

Hassibuan (2003:141) daalam Wiijaya (2012:5) menerangkan motivasi berasal dari perkataan Laatin "bergerak" yang bermaksud menggalakkan atau 


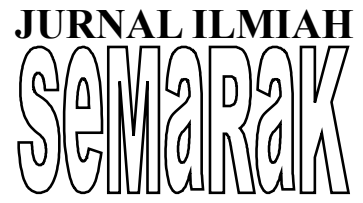

bergerak. Motiivasi dalaam pengurusan hanya bertujuan untuk suumber mannusia secara umum daan baawahan khhususnya.

Soalan mootivasi bagaimana mengarahkan kuasa dan potensi bawahan, bersedia bekerja secara produktif, berjaya mencapai dan merealisasikan matlamat yang dimaksudkan. Motivasi adalah kemahiran dalam mengarahkan pekerja dan organisasi untuk berjaya, supaya keinginan pekerja dan matlamat organisasi dicapai. Motivasi adalah keinginan seseorang yang menyebabkan orang bertindak (Wijaya, 2012: 5).

Berdasarkan kefahaman para ahli di atas, dapat disimpulkan bahwa apa yang dimaksudkan dengan motivasi adalah faktor yang mengarahkan dan mendorong tingkah laku atau keinginan seseorang untuk bertindak dan bekerja untuk memperoleh kebutuhan

\section{Kepuasan Kerja}

Keepuasan keerja adaalah konnsep yaang mempunyai banyak dimensi, bermakna kepuasan kerja dipengaruhi oleh berbagai factor. Kepuasan kerja mempunyai banyak dimensi. Secara umum, tahap yang diperhatikan adalah kepuasan kerja itu sendiri, gaji, pengiktirafan, hubungan antara penyelia dan buruh, dan peluang untuk maju. Setiap dimensi menghasilkan perasaan kepuasan secara keseluruhan dengan kerja itu sendiri, tetapi kerja juga mempunyai definisi yang berbeza untuk orang lain. Kebutuhan-kebutuhan pegawai tidak saja menyangkut kebutuhan yang bersifat fisik, akan tetapi kebutuhan sosial, keamanan, jaminan-jaminan pegawai dan perlindungan. Kebutuhan lain yang menyangkut pegawai, kadang-kadang terkait dengan persoalan kebosanan atas rutinitas yang terjadi, sehingga pegawai membutuhkan sistem rotasi kerja (Rosidah, 2009:301).

Ini juga dinyatakan oleh Sunyoto (2012:26), bahawa kepuasan kerja (kepuasan kerja) adalah keadaan emosi yang menyenangkan atau tidak menyenangkan di mana pekerja memandang kerja mereka. Perasaan ketidakpuasan kerja pekerja timbul apabila jangkaan mereka tidak dipenuhi. Secara formal, kepuasan kerja adalah tahap syarikat seseorang untuk pekerjaannya.

Untuk mengetahui betapa memuaskannya keperluan pekerja, pasukan audit mengumpul data daripada pekerja yang berkaitan dengan gaji, faedah, amalan penyeliaan, bantuan perancangan kerjaya dan maklum balas yang diterima oleh pekerja sebagai kaunter prestasi prestasi. Berdasarkan maklumat dan data, pasukan audit boleh menganalisis tahap kebajikan pekerja dan tahap kepuasan pekerja (Rosidah, 2009:302).

\section{E. Hipotesis Penelitian}

Menurut rangka kerja di atas selaras dengan objektif kajian untuk menjawab 


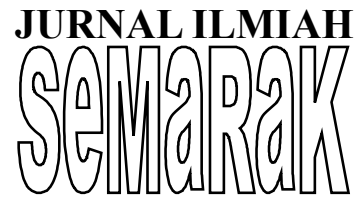

soalan penyelidikan, hipotesis yang diuji adalah seperti berikut:

1. $H_{0}$ : tidak memiliki pengaruh secara parsial (satu per satu) antara variabel gaya kepemimpinan terhadap kepuasan kerja.

$\mathrm{H}_{\mathrm{a}} \quad$ : memiliki pengaruh secara parsial (satu per satu) antara variabel antara gaya kepemimpinan terhadap kepuasan kerja karyawan.

2. $H_{0}$ : tidak memiliki pengaruh secara parsial (satu per satu) antara variabel motivasi kerja terhadap kepuasan kerja.

$\mathrm{H}_{\mathrm{a}}$ : memiliki pengaruh secara parsial (satu per satu) antara variabel antara motivasi kerja terhadap kepuasan kerja karyawan.

3. $\mathrm{H}_{\mathrm{o}}$ : tidak memiliki pengaruh secara parsial (satu per satu) antara variabel gaya kepemimpinan dan motivasi kerja terhadap kepuasan kerja.

$\mathrm{H}_{\mathrm{a}} \quad$ : memiliki pengaruh secara parsial (satu per satu) antara variabel antara gaya kepemimpinan dan motivasi kerja terhadap kepuasan kerja karyawan.

\section{METODE PENELITIAN}

Objek yang digunakan dalam penelitian ini adalah kantor Badan

Meteorologi, Klimatologi dan Geofisika Wilayah 2 Ciputat. Kaedah yang digunakan dalam kajian ini adalah kaedah kajian kes yang merupakan satu kajian deskriptif, dengan kajian ini dijangka akan mendedahkan secara mendalam pembolehubah yang akan dapat menggambarkan analisis pengaruh gaya kepemimmpinan dan lingkungan kerja terhadap kepuasan kerja.

Data yang digunakan menggunakan data primer dan data sekunder. Data primer dalam bentuk wawancara berganda dan dalam bentuk soal selidik sementara data sekunder dalam bentuk benda umum benda penyelidikan (kantor Badan Meteorologi, Klimatologi dan Geofisika).

Teknik pensampelan yang akan diambil dalam kajian ini adalah kemudahan pensampelan, yang merupakan istilah umum yang merangkumi pelbagai prosedur untuk memilih responden. Pensampelan kemudahan bermaksud unit sampel yang diambil mudah untuk dihubungi, tidak menyusahkan, mudah diukur, dan koperasi. Bagi saiz sampel penyelidikan mengikut Roscoe dalam kaedah penyelidikan buku untuk perniagaan (Sugiyono, 2010:52) menyatakan bahawa saiz sampel yang boleh dilaksanakan dalam kajian adalah antara 30 dan 500. Dalam kajian ini, penyelidik menggunakan sampel sebanyak 71 responden.

Sampel yang diambil dalam penelitian ini adalah sebanyak 71 orang responden yang merupakan karyawan pada kantor Badan Meteorologi, 
Klimatologi dan Geofisika Wilayah 2 Ciputat. Menurut Umar (2005: 53) untuk mengetahui saiz sampel, formula Slovin digunakan dengan peratusan elaun $5 \%$, iaitu:

$$
\mathrm{n}=\frac{\mathrm{N}}{1+\mathrm{Ne}^{2}}
$$

Dimana:

n : Ukkuran saampel

$\mathrm{N}$ : Ukkuran poppulasi

e : Perrsentasi keelonggaran

Berdasarkan formula yang dinyatakan di atas, berikut adalah pengiraan sampel penyelidikan seperti berikut:

$\mathrm{n}=\frac{86}{1+86\left(0,05^{2}\right)}$

$\mathrm{n}=\frac{86}{1,215}=71$ Karyawan

Teknik pengumpulan data menggunakan temubual dan pemerhatian dan soal selidik. Sampel yang digunakan sebagai objek kajian ialah 71 pegawai.

\section{HASIIL DDAN PEMMBAHASAN}

A. Gambaran Umuum Badan Meteorologi, Klimatologi dan Geofisika

Seejarah pemerhatian meeteorologi dean geofizik dii Iindonesia bermula paada taahun 1841 bermula deengan pemerhatian dilaakukan secaara individu oleh Dr. Onnen, Ketua Hospital di Bogor. Tahun demi tahun aktiviti tersebut berkembang sesuai dengan semakin diperlukannya data hasil pengamatan cuaca dan geofisika. Pada tahun 1866, kegiatan pengamatan perorangan tersebut oleh Pemerintah Hindia Belanda diresmikan menjadi instansi pemerintah dengan nama Magnetisch en Meteorologisch Observatorium atau Observatorium Magnetik dipimpin oleh Dr. Bergsma (http://www.bmkg.go, diakses pada tanggal 16 September 2015).

Pada tanggal 21 Juli 1947 Jawatan Meteorologi dan Geofisika diambil alih oleh Pemerintah Belanda dan namanya diganti menjadi Meteorologisch en Geofisiche Dienst. Sementara itu, ada juga Jawatan Meteorologi dan Geofisika yang dipertahankan oleh Pemerintah Republik Indonesia , kedudukan instansi tersebut di Jl. Gondangdia, Jakarta. Pada tahun 1949, setelah penyerahan kedaulatan negara Republik Indonesia dari Belanda, Meteorologisch en Geofisiche Dienst diubah menjadi Jawatan Meteorologi dan Geofisika dibawah Departemen Perhubungan dan Pekerjaan Umum. Selanjutnya, pada tahun 1950 Indonesia secara resmi masuk sebagai anggota Organisasi Meteorologi Dunia (World Meteorological Organization atau WMO) dan Kepala Jawatan Meteorologi dan Geofisika menjadi Permanent

Representative of Indonesia with WMO (http://www.bmkg.go.id, diakses pada tanggal 16 September 2015). 


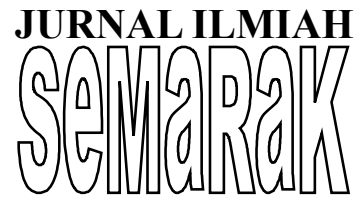

Pada tahun 1965, namanya diubah menjadi Direktorat Meteorologi dan Geofisika, kedudukannya tetap di bawah Departemen Perhubungan Udara. Pada tahun 1972, lalu diganti namanya menjadi Pusat Meteorologi dan Geofisika, suatu instansi setingkat eselon II di bawah Departemen Perhubungan, dan pada tahun 1980 statusnya dinaikkan menjadi suatu instansi setingkat eselon I dengan nama Badan Meteorologi dan Geofisika, dengan kedudukan tetap berada di bawah Departemen Perhubungan.

Pada tahun 2002, dengan keputusan Presiden RI Nomor 46 dan 48 tahun 2002, struktur organisasinya diubah menjadi Lembaga Pemerintah Non Departemen (LPND) dengan nama tetap Badan Meteorologi dan Geofisika. Terakhir, melalui Peraturan Presiden Nomor 61 Tahun 2008, Badan Meteorologi dan Geofisika berganti nama menjadi Badan Meteorologi, Klimatologi, dan Geofisika (BMKG) dengan status tetap sebagai Lembaga Pemerintah Non Departemen. Pada tanggal 1 Oktober 2009 UndangUndang Republik Indonesia Nomor 31 Tahun 2009 tentang Meteorologi, Klimatologi dan Geofisika disahkan oleh Presiden Republik Indonesia,

$$
\text { (http://www.bmkg.go.id, diakses }
$$
pada tanggal 16 September 2015).

\section{B. Penemmuan dan Pembbahasan}

\section{Hasil Ujji Valliditas}

Kesahan didefinisikan sebagai sejauh mana ketepatan dan ketepatan alat pengukur dalam melaksanakan fungsi saiznya. Memahami kesahihan alat ukur bergantung kepada keupayaan alat untuk mengukur objek yang diukur dengan teliti dan tepat. Keputusan pada item soalan mungkin dianggap sah.

Ujian kesahan dilakukan dengan membandingkan nilai $r_{\text {itung }}$ dengan $r_{\text {tabel, }}$, dengan membandingkan nilai $\mathrm{r}_{\text {hitungan }}$ dari output (Corrected Item-Total Correlation) dengan $\mathrm{r}_{\text {table }}$, jika bilangan $r$ lebih besar daripada rtable maka item soalan sah, tetapi jika $r_{\text {hitung }}$ lebih kecil dari pada $\mathrm{r}_{\text {tabel }}$ maka butir pertanyaan tersebut tidak valid (Ghozali, 2011:54). Ditemukan nilai $r_{\text {tabel }}$ sebesar 0,235. Didapat dari jumlah kasus - 2, atau 71 $2=69$, tingkat signifikansi 5\%, maka didapat $r_{\text {tabel }} 0,235$. Berikut ini adalah hasil uji validitas pada variabel penelitian (gaya kepemimpinan, motivasi kerja dan kepuasan kerja pegawai):.

\section{Tabel 1}

\section{Hasil Uji Validitas}




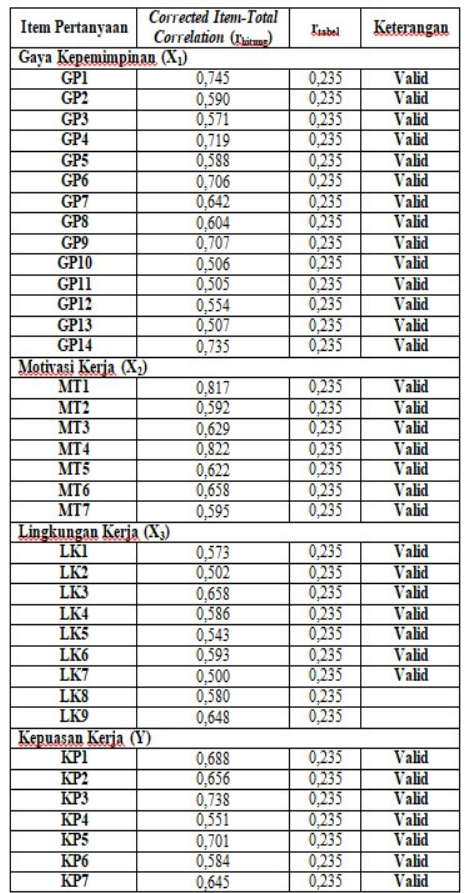

Sumber: Data Diolah

Hasil try out tersebut, diperoleh data yang menyatakan bahwa dari item pertanyaan yang diberikan kepada 98 responden ditemukan nilai Corrected Item-Total Correlation $\left(\mathrm{r}_{\text {tabel }}\right)$ lebih besar dari nilai $0,235\left(\mathrm{r}_{\text {tabel }}\right)$ yang berarti valid maka dapat dilanjutkan ke penelitian berikutnya.

\section{Uji Reliabilitass}

Ujian kebolehpercayaan ini digunakan untuk menguji konsistensi data dalam tempoh masa tertentu, iaitu untuk menentukan sejauh mana pengukuran yang digunakan boleh dipercaya atau dipercayai. Pembolehubah alpha cronbach dikatakan mempunyai nilai yang lebih besar daripada 0.70 yaang bermaksud bahawa insttrumen teersebut boleh digunakan sebagai pengumpul data yang boleh dipercayai, yang merupakan hasil pengukuran relatif pekali jika pengukuran berulang dibuat. Ujian kebolehpercayaan inni berrtujuan unntuk mellihat konsistensi (Ghozali, 2011:48). Berikut ialah keputusan ujian kebolehpercayaan:

Tabel 2 Hasil Uji Reliabilitas

\begin{tabular}{|l|c|c|c|}
\hline \multicolumn{1}{|c|}{ Item Pertanyaan } & $\begin{array}{c}\text { Cronbacl's } \\
\text { Alpha }\end{array}$ & $\begin{array}{c}\text { NOf } \\
\text { Item }\end{array}$ & Keterangan \\
\hline Gaya Kepemimpinan $\left(\mathrm{X}_{1}\right)$ & 0,911 & 14 & Reliabel \\
\hline Motivasi Kerja $\left(\mathrm{X}_{2}\right)$ & 0,885 & 7 & Reliabel \\
\hline Lingkungan Kerja $\left(\mathrm{X}_{3}\right)$ & 0,854 & 9 & Reliabel \\
\hline Kepuasan Kerja $(\mathrm{Y})$ & 0,873 & 7 & Reliabel \\
\hline
\end{tabular}

Summber: Daata primmer yaang dilah

Berdasarkan tabel di atas terlihat bahwa variabel yang terdiri dari motivasi kerja dan iklim organisasi kepuasan kerja karyawan memiliki data yang reliabel, hal ini terlihat dari nilai cronbach alpha lebih besar dari 0,70. Hal ini membuktikan bahwa penelitian ini dapat dilanjutkan.

\section{Hasil Ujji Asumsi Klaasik}

\section{a. Hasil Uji Normalitas Daata}

Gambar 1

\section{Hassil Uji Normalitas Dsata}

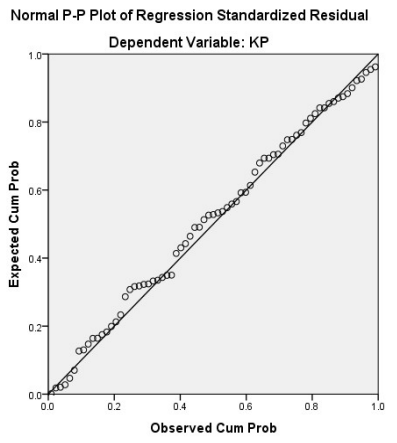

Dari graf di atas, dapat dilihat bahawa data penyelidikan mempunyai pengedaran dan pengedaran yang normal kerana data berpusat pada nilai purata dan 


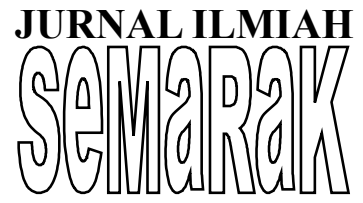

median atau nilai plot PP terletak secara menyerong, jadi boleh dikatakan bahawa data diedarkan secara normal.

\section{b. Hasil Ujii Multikoolinearitas}

Tabel 2

Haasil Ujji Multikoolinearitas

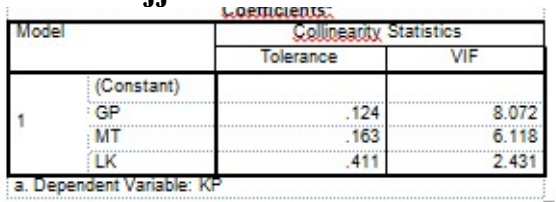

Sumber: Data primer yang diolah

Nilai VIF yang dibenarkan hanya mencapai 10 dan mempunyai nilai toleransi melebihi 0.10 . Kemudian data di atas dapat dipastikan bahawa tidak ada gejala multicollinearity. Kerana data di atas menunjukkan bahawa nilai VIF lebih kecil dari 10 .

\section{c. Hasiil Ujii Heterooskedastisitas}

Gambar 2

Hassil Ujii Heterooskedastisitas

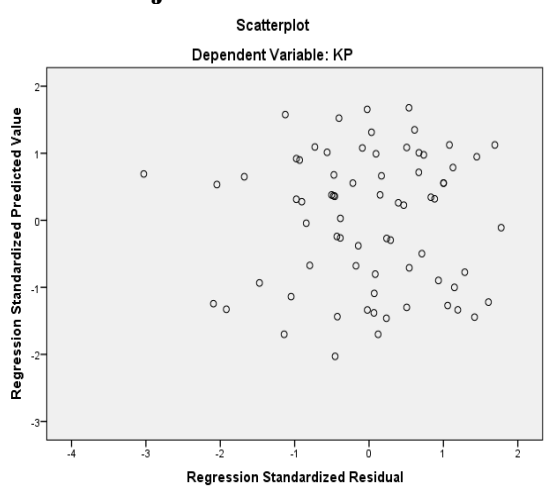

Sumber: Data primer yang diolah

Dalam gambar di atas, dapat dilihat bahawa mata yang tersebar di atas dan di bawah sifar pada paksi $Y$ dan tidak ada corak tertentu. Oleh itu dalam persamaan regresi berganda linear dalam model ini tidak ada gejala atau tidak ada heteroscedasticity.

4. Haasil Analiseis Koeffisien Rgegresi Liniear Beraganda

a. Haasil Koeefisien Deeterminasi (Uji Adjusted $\mathrm{R}^{2}$ )

Tabel 3

Haasil Koefisieen Deeterminasi (Adjusted $\mathbf{R}^{2}$ )

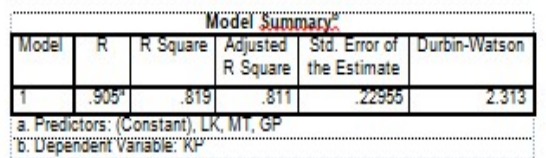

Sumber: Data primer yang diolah

Berdasarkan jadual di atas, nilai yang diselaraskan $\mathrm{R}$ persegi adalah 0,811 (81,1\%), menunjukkan bahawa dengan menggunakan model regresi yang diperolehi di mana pembolehubah bebas iaitu gaya kepemimpinan, motivasi kerja dan lingkungan kerja memiliki pengaruh terhadap kepuasan kerja berubah sebanyak $81,1 \%$. Sementara baki $18,9 \%$ dijelaskan oleh faktor atau pembolehubah lain yang tidak diketahui dan tidak termasuk dalam analisis regresi ini, seperti kompensasi, budaya organisasi dan lain - lain.

\section{b. Hasiil Koefisieen Persaamaan Ujji} Regresi Liniear Beraganda

Analisis regresi linier berganda adalah ujian yang digunakan untuk menentukan berapa banyak pengaruh antara pembolehubah 


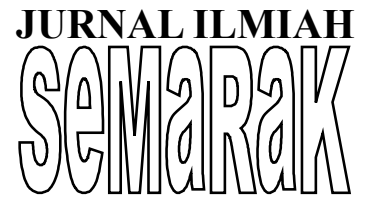

bebas

(gaya

kepemimpinan, motivasi kerja dan lingkungan kerja) pada pembolehubah yang bergantung kepada (kepuasan kerja). Hasil pengaruh regresi linier berganda gaya kepemimpinan, motivasi kerja dan lingkungan kerja Mencari Pengubah kepuasan kerja adalah seperti berikut:

Tabel 4

Haasil Koefiisien Perssamaan Reegresi Liinier Beerganda

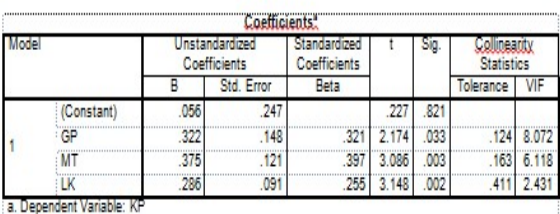

Sumber: Data primer yang diolah Jadual di atas boleh dirumuskan persamaan regresi untuk menentukan kesan atribut produk, promosi dan pencarian pelbagai ke arah menaip jenama seperti berikut:

$\mathrm{Y}=\mathrm{a}+\mathrm{bx} 1+\mathrm{bx} 2+\mathrm{bx} 3+\mathrm{bx}$

$\mathrm{Y}=0,056+0,322 \mathrm{X}_{1}+0,375 \mathrm{X}_{2}+$ $0,286 \mathrm{X}_{3}$

Keterangan :

Y : kepuasan kerja

$\mathrm{X} 1$ : gaya kepemimpinan

$\mathrm{X} 2$ : motivasi kerja

X3 : lingkungan kerja

Koefisien persamaan regresi linear berganda di atas boleh ditafsirkan sebagai pekali regresi malar 0.056 menunjukkan bahawa jika gaya kepemimpinan, motivasi kerja dan lingkungan kerja adalah sifar, nilai kepuasan kerja ialah 0,056 unit atau 5,6\%. Perhatikan bahawa pembolehubah lain dianggap malar. Variabel gaya kepemimpinan 0,322 menunjukkan bahawa jika pemboleh ubah gaya kepemimpinan meningkat sebanyak 1 unit, ia akan meningkatkan kepuasan kerja sebanyak 0,322 unit atau $32,2 \%$. Variabel motiivasi keerja 0,375 menunjukkan bahawa jika kenaikan nilai motivasi kerja sebesar 1 unit, ia akan meningkatkan motivasi kerja sebanyak 0,375 unit atau 37,5\%. Lingkungan kerja variabel 0,286 menunjukkan bahawa jika variasi vaiabel lingkungan kerja sebanyak 1 unit maka ia akan meningkatkan kepuasan kerja sebanyak 0,286 unit, dengan syarat pembolehubah lain dianggap tetap.

\section{Hasiil Ujji Hipootesis}

\section{a. Hasisl Uji Sttatistik F}

Ujian $F$ telah dijalankan untuk melihat gayaa keepemimpinan, motiivasi kerja dan lingkungan kerja secara keseluruhan pada pemboleh ubah beralih jenama. Berikut adalah keputusan ujian serentak, keputusan ujian ANOVA diperolehi seperti berikut:

Tabel 5

Hasil Uji Statistik F (Simultan) 


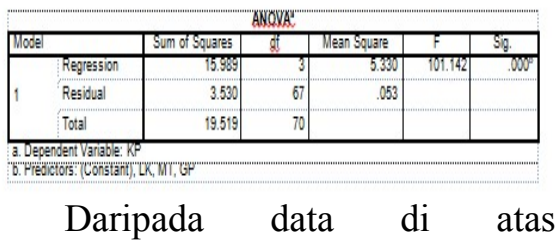

memperoleh nilai signifikan 0,000 bermakna bahawa peruntukan nombor dua terpakai dalam kajian ini yang $\mathrm{H}_{\mathrm{o}}$ ditolak dan $\mathrm{H}_{\mathrm{a}}$ diterima. Keputusan ujian $\mathrm{F}$ ini menyatakan bahawa keputusan ujian serentak di atas adalah benar.

Dalam kajian ini, nilai $\mathrm{F}$ yang dikira adalah 101,142 yang lebih besar daripada nilai $\mathrm{F}_{\text {tabel }}$ 2,74. Ini bermakna bahawa peruntukan nomor empat adalah benar. Sebagai kesimpulan, terdapat pengaruh linier antara variabel bebas dan pemboleh ubah yang bergantung.

\section{b. Hasil Ujii t (Ujii Seccara Paarsial)}

Tabel 6

Haasil Ujji t (Ujii Secaara Parsial)

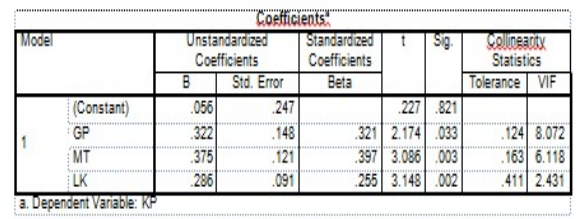

Berdasarkan keputusan ujian $t$, dapat dilihat bahawa semua variable bebas sebahagiannya mempengaruhi kepuasan kerja.

\section{KESIMPULAN DAAN SARAN}

\section{A. Kesimpulan}

Kajian ini dijalankan untuk menentukan kesan gaaya kepeemimpinan, mootivasi keerja dan linggkungan kerja yang dicari pada kepuuasan kerrja. Berdasarkan hasil penyelidikan yang dijelaskan dalam bab sebelumnya, beberapa kesimpulan dapat diambil seperti berikut:

1. Hasil kajian menyatakan bahawa sebahagian atau berdasarkan keputusan ujian t menunjukkan bahawa variable gaya kepemimpinan berpengaruh terhadap kepuasan kerja.

2. Hasil kajian menyatakan bahawa sebahagian atau berdasarkan keputusan ujian $\mathrm{t}$ menunjukkan bahawa variable motivasi kerja berpengaruh terhadap kepuasan kerja.

3. Hasil kajian menyatakan bahawa sebahagian atau berdasarkan keputusan ujian t menunjukkan bahawa variable lingkungan kerja berpengaruh terhadap kepuasan kerja

4. Hasil peneelitian mennyatakan bahhwa secaraa simmultan attau berdaasarkan hasil ujii $\mathrm{F}$ menunjuukkan bahwwa terdapaat pengaruuh siggnifikan antaara variablew gaaya keepemimpinan, mottivasi keerja dan linggkungan keerja teerhadap keppuasan kerrja.

\section{B. Saran}

Hasil kajian inngin meemberikan beeberapa saaran yaang daapat diisampaikan, yiaitu:

1. Sebaiknya Kantor Balai Besar Bmkg Wilayah 2 Ciputat lebih memperbaiki dalam hal meningkatkan gaya kepemimpinan dengan mengawasi 


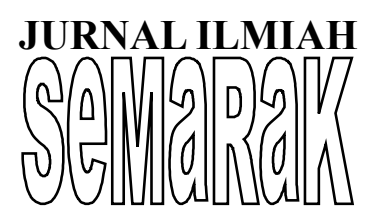

kegiatan pegawai agar lebih

meningkatkan kepuasan kerja

pegawainya

2. Lebih meningkatkan motivasi kerja dengan memberikan gaji sesuai dengan kebutuhan hidup pegawainya.

3. Sebaiknya Kantor Balai Besar Bmkg Wilayah 2 Ciputat lebih meningkatkan lingkungan kerja dengan meningkatkan fasilitas dari Kantor Balai Besar Bmkg Wilayah 2 Ciputat.

\section{DAFTAR PUSTAKA}

Ardana, I Komang, Muijati, Ni Wayan \& Utama, I Wayan Mudhiartha, "Sumber Dava Manusia", Graha Ilmu, Yogyakarta, 2012.

Ghozali, Imam, "Aplikasi Analisis Multivariat Dengan Program SPSS 19", Badan Penerbit Universitas Dipenogoro, Semarang, 2011.

Hasibuan, Melayu, "Manaiemen Sumber Daya Manusia", PT. Bumi Aksara, Jakarta, 2012.

Rosidah, Ambar Teguh Sulistiyani, "Manajemen Sumber Daya Manusia", Graha Ilmu, Yogyakarta, 2009.

Sunyoto, Danang, "Sumber Dava Manusia (Praktik Penelitian)", Center For Academic Publishing Service), Yogyakarta, 2012.

Riani, Asri Laksmi, "Manajemen Sumber Daya Manusia, Graha Ilmu, Yogyakarta, 2013.

Wijaya, Andree, "Pengaruh Kemampuan Dan Motivasi Terhadap Kineria Karyawan”, Jurnal Sekolah Tinggi Ilmu Ekonomi Widya Manggala, Semarang, 2012.

Hariandja, Marihot Tua Efendi, "Manajemen Sumber Daya Manusia", Grasindo, Jakarta, 2007.
Sunyoto, Danang, "Sumber Daya Manusia (Praktik Penelitian)", Center For Academic Publishing Service, Yogyakarta, 2012.

Swastha, Bashu, Ibnu Sukotio, "Pengantar Bisnis”, Liberti, Yogyakarta, 2010

Sutrisno Edi, "Manajemen Sumber Daya Manusia”, Kencana, Jakarta, 2016.

Bangun, Wilson, "Manajemen Sumber Daya Manusia”, Erlangga, Jakarta, 2012.

Kasmir, "Manajemen Sumber Daya Manusia (Teori dan Praktik)”, PT. Raja Grafindo Persada, Jakarta, 2016.

Pasaribu, V. L. D., \& Krisnaldy, K. (2018). ANALISIS KEPUASAN JAMA'AH PADA KINERJA DEWAN KEMAKMURAN MASJID ALHIDAYAH PERIODE TAHUN 2017. KREATIF: Jurnal Ilmiah Prodi Manajemen Universitas Pamulang, 6(4), 41-51. 